\title{
Pragmatic Identity in China and the US Real Estate Advertising: Critical Pragmatic Analysis
}

\author{
Xu Yilin \\ Faculty of Business English, Guangdong University \\ of Foreign Studies, Guangzhou, China.
}

\begin{abstract}
This research attempts to find out similarities and differences of values through comparison of pragmatic identities constructed in china real estate advertising and that in the US real estate advertising. The study selected 50 Chinese and 50 American electrical real estate advertising.to analyze pragmatic identities constructed in these advertisements and concluded 16 kinds of identities. Both American and Chinese advertisers tend to presuppose consumers' identity to advertise real estate although explicit linguistic resources regarding identity such as champion are also used to construct identity. Advertisers tend to appeal and provoke consumers' purchase desire so that they construct different identities according to Maslow's hierarchy of needs especially belonging (love) and self-realization needs. As regard to differences of identities embodied in Chinese and American real estate advertising, Hofstede's cultural dimensions are adopted to explain.
\end{abstract}

Keywords: Real estate advertisement, Pragmatic identity, Critical pragmatic analysis

\section{INTRODUCTION}

Real estate plays an important role in our daily life and real estate advertising aims to persuade consumers to spend relatively large amount of money on buying house. Additionally, we see tendency of globalization in real estate market and more Chinese are willing to buy house in the US. Thus, real estate advertisement filled with skills of persuasion is worth to study.

Although there are certain researches on comparison between china and the US real estate advertisement from perspective of critical discourse analysis, relatively small studies attempt to analyze pragmatic identities constructed in real estate advertising. Analysis on pragmatic identity constructed in real estate advertisement can strengthen our understandings on linguistic features, persuasion strategies and ideologies of real estate advertisement so that it can remind consumers unequal relationship and unreal information included in the advertisement and thereby urge advertisers to check their advertising carefully which helps to create more healthy advertising world. Thus, the paper will find out similarities and differences of pragmatic identity constructed to persuade consumers to purchase house in Chinese and American real estate advertisement from the perspective of critical pragmatic analysis. 
Yilin, X. (2020) Pragmatic Identity in China and the US Real Estate Advertising: Critical Pragmatic Analysis. Advances in Social Sciences Research Journal, 7(5) 393-404.

Based on the aim, the following research questions need to be answered: 1) What kinds of pragmatic identities constructed in china and the US real estate advertising are? What's the distribution among all selected discourses? 2) What kinds of linguistic or pragmatics resources used in constructing these pragmatic identities? 3) What kinds of values embodied in these identities and selected linguistics or pragmatics resources?

This paper is structured as follows: the following section will review researches on real estate advertising and point out research gaps. Major theories and methodology adopted in the research will be introduced in the third and fourth section. After analysis, the reasons why advertisers adopt such pragmatic resources will be discussed.

\section{LITERATURE REVIEW}

Linguistic researches on real estate advertising have been studied from different branches including systemic functional linguistic (SFL), critical discourse analysis (CDA) and pragmatics. Studies on real estate advertising from SFL and CDA are always based on combination of Fairclough's threedimensional framework and appraisal system to find out ideologies and values hided in real estate advertisement. For example, Li (2008) also combined Fairclough's three-dimensional framework of discourse and the transitivity system from systemic functional grammar to explore ideologies concealed in Chinese real estate advertising [6]. Li Ying (2014) studied how advertisement appeal to consumers' emotion through combination of Fairclough's three-dimensional framework of discourse, the transitivity system and mood-modality system [7]. Besides, intertextuality is also foci of researches on real estate advertisement from perspective of CDA and SFL. For instance, Robinson (1996) examines the intertextuality of White Cultural Matrix and the Language of Nonverbal Advertising in housing segregation although the study mainly addresses the racism instilled in the housing advertisements [10]. Zhu (2008) found that there are three kinds of intertextuality in real estate advertising [13] while Lu (2011) combined social semiotics methods and SFL to study intertextuality of real estate advertising [9]. Regarding to pragmatic studies on real estate advertising, most are based on presupposition and adaptative theory [11-12] although several researchers have adopted critical pragmatic analysis to study pragmatic identities embodied in real estate advertisement [3]. Although scholars conduct comparison of identities constructed in American and Chinese real estate advertisement, their conclusion that American real estate advertisers would not presuppose identity in advertisements is doubtful [4].

Although these studies have found that real estate advertising will presuppose identity of consumers to some extent, relatively less researchers study how advertiser construct these identities. In addition, studies on cross-cultural comparison of identities constructed in real estate advertisement are relatively uncommon in linguistic. As for selection of real estate advertisement, most researchers adopt advertisement in newspaper rather than social media or search engine which nowadays are the major channel that citizen retrieve information. Thus, this study attempts to collect real estate advertisements published on social media and conducts cross-cultural analysis on linguistic resources of identity construction used by real estate advertisers from perspective of critical pragmatic analysis. 


\section{Critical pragmatic analysis}

\section{THEORETICAL FOUNDATION}

Mey (1993) [9] put forward critical pragmatics in his book pragmatics: an introduction in which he stressed importance of language user and considered that pragmatics shall help readers realize power disbalance in language use. Critical pragmatic analysis as a branch of pragmatics pays attention to ideologies and values and aims to explore implicit problems such as power control hided in social context [1]. Different from critical discourse analysis, critical pragmatic analysis not only focus on power and ideologies but also focus on individual discourse combining with different theories such as deixis, presupposition, implication and so on [2].

\section{Pragmatic identity}

Chen (2018) integrates relevant researches on identity construction and puts forward pragmatic identity to differentiate researches of other disciplines [2]. Pragmatic identity is closely related with discourse and is different from individual social identity existing before dialogue. It can be 1) speaker's own identity, 2) listener understanding's identity or 3) the third party mentioned by speaker. Chen (2018) [2] considers that researches on identity from pragmatic perspective cannot only focus on types of identities and relationship between identity and discourse but rather focus on the reason why communicators select such identity, how these identities fulfill communication aim and what effect have been achieved. Thus, the following questions shall be answered: 1) how construction of identity influences meaning of language in the discourse? 2) how construction of these identities fulfills communication? 3) how construction of these identities influences interpersonal meaning? 4) how construction of identity influence selection of language expression? 5) how construction of identity influences appropriateness of language use?

In order to answer the above questions, five research approaches are put forward: 1) identity as interpretive resources to understand meaning of discourses 2) identity as illocutionary or transactional resource to see how communicator construct identity to fulfill communication aims. 3) identity as interpersonal resources to see how communicator select and construct such identities to be close to or distance others. 4) identity as explanatory resource to explain the reason why such features of discourse exist. 5) identity as evaluative resource to judge appropriateness of discourse in specific context [2].

The study aims to figure out identity constructed in China and the US real estate advertisement from pragmatic perspective and how these identities fulfill aims of advertisers, so that the second method mentioned in the above will be adopted. In addition, the paper attempts to discuss motivation why advertisers construct these identities and values or ideologies embodied in construction of identities from critical pragmatic analysis perspective so that this study contribute to improve readers' awareness to judge real estate advertisement.

\section{Data collection}

\section{METHODOLOGY}

According to statistic, only $19 \%$ of consumers purchase real estate from home books or real estate magazines while the internet is used by almost $100 \%$ of people to gain information about real estate nowadays. Thus, online real estate advertisements are selected as data of this research. Advertisement of Vanke and Poly real estate company are chosen as representative of Chinese real estate advertising while advertisement of Lennar and D.R. Horton are that of American real estate 
Yilin, X. (2020) Pragmatic Identity in China and the US Real Estate Advertising: Critical Pragmatic Analysis. Advances in Social Sciences Research Journal, 7(5) 393-404.

advertising discourse. These companies are not only famous and major home builders in China and the US but also well-known for their advertisement. Thus, identities embodied in advertisement of these companies are representative and reflect consumers' values in some extent. The research will choose 25 advertisements of each company which were published from 2017 to 2018 and the data is 100 advertisements in total.

Based on differences of social media between China and the US, We-chat official accounts are major channel to collect advertisements of Vanke and Poly while advertisement of Lenna and D.R. Horton are collected from Facebook. "Fang di chan jing xuan" (Choice of Real Estate) and "Fang di chan guang gao ku" (Ad Bank of Real Estate) are famous and popular official accounts of real estate among Chinese consumers, adman and advertisers so that advertisements of Vanke and Poly will be collected from these two official accounts through reviewing history news. However, collection of the US real estate advertisement is relatively complicated. Advertisements of D.R. Horton are collected from corporate official Facebook accounts through searching keywords "D. R. Horton homes" and "D. R. Horton homes flyer".

Information of Lennar's Facebook official account is mainly about house and room types such as 'Would you LOVE to be eating a nice meal in this dining area?!', so advertisements of Lennar are collected from Facebook accounts of its advertising companies which are in responsible for online advertising such as Peakseven.com, propelmg.com and tarabasoftware.com. It shall be noticed that not all online advertising flyers shown in the above source will be selected. Flyers only involve area of real estate, name of home builder or celebration of festivals will not be selected such as a flyer only includes texts "Poly Costal Mansion" and "540 thousand m² private coast".

\section{Data processing}

The paper mainly focuses on texts which appear on online advertising flyer so that advertising texts of flyer will be captured and written down while texts provide information about location or size of house are deleted. Take one of Poly real estate company advertisements as an example. In that flyer, sentence "Poly AI Shang Li, enjoy more for love" will be written down but sentences such as "Yang jiaping business circle" and "58-78 $\mathrm{m}^{3}$ " will be deleted.

\section{Categories of identities and distribution}

\section{ANALYSIS}

Table 1 shows all identities constructed in all discourse and distribution of each identity among all identities.

From the table below, we can find that winner (18\%) is the most frequent identity constructed in china and the US real estate advertising followed by family (12\%) and individuality. The following tables respectively describes identities constructed in the US and China real estate advertising. 
Table 1 Overall identities and Distribution of identities

\begin{tabular}{|c|c|c|}
\hline Identity & Amount & Percentage of total amount \\
\hline Winner / Champion/ Victor (pursue victory) & 18 & $18 \%$ \\
\hline Family (love home) & 12 & $12 \%$ \\
\hline Individuality & 8 & $8 \%$ \\
\hline Peace seeker & 7 & $7 \%$ \\
\hline Dreamer & 7 & $7 \%$ \\
\hline high-tech lover & 7 & $7 \%$ \\
\hline Money saver & 6 & $6 \%$ \\
\hline Nature lover & 6 & $6 \%$ \\
\hline Child (full of imagination) & 5 & $5 \%$ \\
\hline Extravert & 5 & $5 \%$ \\
\hline Enjoyer & 5 & $4 \%$ \\
\hline Simple life seeker & 4 & $3 \%$ \\
\hline Quality prioritized realist & 3 & $3 \%$ \\
\hline Time saver & 3 & $3 \%$ \\
\hline Child education prioritized parent & 3 & $2 \%$ \\
\hline Sport lover & 2 & $7 \%$ \\
\hline Other & 7 & $5 \%$ \\
\hline
\end{tabular}

Table 2 Identities in the US real estate advertising

\begin{tabular}{|c|c|c|}
\hline Identity & Amount & Percentage of total amount \\
\hline Winner / Champion/ Victor (pursue victory) & 8 & $8 \%$ \\
\hline Family (love home) & 6 & $6 \%$ \\
\hline High-tech lover & 6 & $6 \%$ \\
\hline Money saver & 6 & $6 \%$ \\
\hline Enjoyer & 5 & $5 \%$ \\
\hline Simple life seeker & 4 & $3 \%$ \\
\hline Dreamer & 3 & $3 \%$ \\
\hline Extravert & 3 & $3 \%$ \\
\hline Quality prioritized realist & 3 & $2 \%$ \\
\hline Individuality & 2 & $2 \%$ \\
\hline Child (full of imagination) & 2 & $1 \%$ \\
\hline Nature lover & 1 & $1 \%$ \\
\hline Sport lover & 1 & 0 \\
\hline Peace seeker & 0 & 0 \\
\hline Time saver & 0 & 0 \\
\hline Child education prioritized parent & 0 & $5 \%$ \\
\hline Other & 5 & \\
\hline
\end{tabular}

The top 2 identities that the US real estate advertisers tend to construct are winner (8\%) and family $(6 \%)$, the result same with table 1 . However, high-tech lover (6\%), money saver (6\%) and enjoyer (5\%) are salient among all identities constructed by the US real estate advertisers and different from the overall result. In the meanwhile, peace seeker never appears in the US real estate advertising but it takes up $7 \%$ of total amount. 
Yilin, X. (2020) Pragmatic Identity in China and the US Real Estate Advertising: Critical Pragmatic Analysis. Advances in Social Sciences Research Journal, 7(5) 393-404.

Table 3 Identities in China real estate advertising

\begin{tabular}{|c|c|c|}
\hline Identity & Amount & Percentage of total amount \\
\hline Winner / Champion/ Victor (pursue victory) & 9 & $9 \%$ \\
\hline Peace seeker & 7 & $7 \%$ \\
\hline Family (love home) & 6 & $6 \%$ \\
\hline Individuality & 6 & $6 \%$ \\
\hline Nature lover & 5 & $5 \%$ \\
\hline Dreamer & 4 & $4 \%$ \\
\hline Child (full of imagination) & 3 & $3 \%$ \\
\hline Time saver & 3 & $3 \%$ \\
\hline Child education prioritized parent & 3 & $3 \%$ \\
\hline Extravert & 2 & $2 \%$ \\
\hline high-tech lover & 1 & $1 \%$ \\
\hline Sport lover & 1 & $1 \%$ \\
\hline Quality prioritized realist & 0 & 0 \\
\hline Money saver & 0 & 0 \\
\hline Enjoyer & 0 & 0 \\
\hline Simple life seeker & 0 & 0 \\
\hline Other & 2 & $2 \%$ \\
\hline
\end{tabular}

Winner (9\%) also the top identity constructed in China real estate advertising but it is followed by peace seeker (7\%) rather than family (6\%). Different from American real estate advertisers, identities like enjoyer, money saver, simple life seeker and quality prioritized realist do not appear in China real estate advertising.

The above tables demonstrate all identities embodied in 100 advertisement. The author divides identities into 16 types and the following section will show specific advertisements of each type.

\section{Winner / Champion/ Victor (pursue victory)}

Real estate advertisers construct identity of winner according to consumers' willingness to success. Advertisers tend to consider consumers as successor or potential successor.

a. Make them green with envy.

b. Take your first steps with Lennar.

c. 据层峰, 执掌天下。窗外河景, 优雅办公, 更显从容有度。高端商务空间, 处处先人一步 (People in higher position rule the world. River view outside the window with elegant office makes you relaxed and calm. High-end business space helps you lead others one step ahead.)

d. 游戈商场与运动场是商界精英也是运动健将 (Business elites and athletes are business and sports fields

From the above examples, we can find that advertisers use different expression to construct successor in journey of life and construct identity who has power. The US and China real estate advertisers tend to convey that those who own or buy house built by their company are successful and envied by others. 


\section{Family (love home)}

House is always living place of family so that advertisers construct identity of family to show their consumers their houses suitable for family living and those who live here love each other.

a. love is a beautiful family, a beautiful home.

b. one roof, two homes, three generations.

c. 啥是佩奇 是家人对团圆的心心念念 (Paige is the family's longing for reunion)

d. 保利爱尚里 为爱享更多 (Poly for more love)

From specific advertisements, we find that both American and Chinese real estate advertisers tend to construct identity of home lover but American real estate advertisers stress family who are living together while Chinese stress parents who miss their children.

\section{Individuality}

Individuality in this paper means that person are free to choose their lifestyle according to their desire.

a. your home, your style

b. Live beautifully

c. 仰天大笑出门去 我辈岂是蓬蒿人 等一个最酒脱的人 (Leaving home laughing with head holding high, wouldn't my generation be a basil person. Waiting for the most free and easy person.)

d. 人生得意须尽欢 莫使金樽空对月 等一个最性情的人 (When hopes are won, oh! drink your fill in full delight. And never leave your wine-cup empty in moonlight! Waiting for the most passionate person)

From above examples, we can find that identity of individuality embodied in Chinese and American real estate advertising is similar.

\section{Peace seeker}

a. 低坡屋顶下,那种平和淡泊的心境氛围, 只有真正的名仕巨富才能心领神会、视为知己。 (Under the low-sloping roof with calm and peace mood, can only be understood by the real rich and famous.)

b. 一生领导潮流, 难得随波逐流。风云间隙, 何妨放下一切, 让思想尽情随波逐流。

(Leading the trend throughout life, it is rare to follow the trend. Between the wind and the clouds, why not let go of everything and let your mind drift.)

Chinese real estate advertisers tend to construct identity of peace seeker while we cannot find such identity in American real estate advertising.

\section{Dreamer}

a. America's dream

b. Take your first steps with Lennar

c. 1 年以前, 它力排众议, 坚持认为自己, 是一只喜欢冒险的百慕大龙虾, 距离梦想只有 17 英里。(1 year ago, it stood out from the crowd and insisted that it is an adventurous Bermuda lobster only 17 miles away from the dream) 
Yilin, X. (2020) Pragmatic Identity in China and the US Real Estate Advertising: Critical Pragmatic Analysis. Advances in Social Sciences Research Journal, 7(5) $\underline{393-404}$

d. 作为龙的传人 喧器都市中 初心不改 (As the heir to the nation of dragon, we keep ourselves in crowd city)

Dreamer, person pursuing dream, is also an identity that advertisers frequently construct. American real estate advertisers tend to equal buying house to American's dream while Chinese real estate advertisers tend to construct dream who stick to their original dream.

\section{High-tech lover}

a. life reimagined. Everything's included. Every room's connected

b. home is where wi-fi connects automatically

c. 天之境 心至悦 全屋智能家居系统 更新生活想象 (The realm of heaven and joy with whole house smart home system updates your imagination on life)

Real estate advertisers will stress automatic feature of house so that they will correspondingly construct identity of high-tech lover. Moreover, expressions of such identity are similar in Chinese and American real estate advertising.

\section{Money saver}

a. $\$ 1$ moves you in

b. home is where the least is.

American real estate advertisers will stress low price and promotion of their house, implying that consumers are money saver while such expressions are not found in selected Chinese real estate advertising.

\section{Nature lover}

a. Start fresh. Start new

b. 300亩公园在楼下 乐活美景, 恋恋四季 (A park with 300 acres is nearby your house. Love nature, happy life)

Both American and Chinese real estate advertisers construct identity of nature lover through stressing environment of house.

\section{Child (full of imagination)}

a. Don't forget to become a child again

b. you've spent your life designing it. We'll take care of the rest.

c. 乐在百万方大城 做个无忧小王子 童话世界不寂寞 (Have fun in Million Square City and be a carefree little prince)

d. 教科书可以丢了, 练习册可以丢了, 千万别把童心和好奇心也丢了 (Textbooks and exercise books can be lost but do not lose your innocence and curiosity)

Expressions used to construct identity of child are similar in both American and Chinese real estate advertisers.

\section{Extravert}

a. love is ... affordable country club living

b. Join our neighbourhood -70 happy families and counting! 
c. 文庙街的酒, 一口又一口, 如今酣畅碰杯, 还是那群老友 (The wine on Wenmiao Street, bite after bite, is still the old friends of the group)

d. 人民公园的郁金香, 开了又开, 每一次, 你都不曾缺席 (Tulips in People's Park have been opened and opened again. You are always here)

Extravert in this paper means person who like social connection. American real estate advertisers stress club living while Chinese stress friends.

\section{Enjoyer}
a. home for the holidays
b. love is ... vacation-style living.

\section{Simple life seeker}
a. Live a little. With Lennar
b. Simplistic + functional. Open architecture \& modern technology

\section{Quality prioritized realist}

a. quality, cost, delivery and performance are a no miss with Lennar

b. quality. Value. Integrity.

c. Enjoyer, simple life seeker and quality prioritized realist are identity embodied only in American real estate advertising.

\section{Time saver}

Time saver is identity embodied only in Chinese real estate advertising.

a. 时间是城市生活最大的奢侈 5分钟即达丰盛生活圈层 (Time is the biggest luxury of urban life. We can enable you 5 minutes to reach the bustling business circle)

b. 上学, 放学, 直接点 (Cost less time on the way to school)

\section{Child education prioritized parent}

a. 知书识礼 择邻而居 (Books bring knowledge, choose qualified neighbors)

b. 只有好的土壤, 能让孩子的天赋茁壮成长 (Only good soil can make children's talents thrive)

Child education prioritized parent is also identity embodied only in Chinese real estate advertising.

\section{Sport lover}

a. Enjoy outdoor living

b. 呼气, 吸气, 直接点 (Convenient to outdoor living)

Although identity of sport lover is relatively rare among selected advertisements, both American and Chinese real estate advertisers will construct identity of sport lover.

\section{Ways to construct identities}

\section{Explicit expression}

We can find that real estate advertisers will use specific words of showing identity. For example, "love is a beautiful family, a beautiful home" (2a) to explicitly construct identity of family and “游式 
Yilin, X. (2020) Pragmatic Identity in China and the US Real Estate Advertising: Critical Pragmatic Analysis. Advances in Social Sciences Research Journal, 7(5) 393-404.

商场与运动场是商界精英也是运动健将”(1d) with words like “商界精英” (business elite) and “运动 健将” (athletes) to construct identity of winner or people in pursuit of victory. In addition, Chinese real estate advertisers will use such expression like "verb + noun" to explicitly construct identity. For example, “据层峰 , 执掌天下” (1c) constructs identity of successor who own power.

\section{Implicit expression}

Real estate advertisers will presuppose consumers identity or desire. For example, "Make them green with envy” (1a) and “300亩公园在楼下乐活美景 , 恋恋四季” (8b) presuppose identity of consumers who desire to success and love fresh environment. In general, real estate advertisers use implicit expression more than explicit expression.

\section{Motivation of constructing identities}

From the above analysis, we find that real advertisers construct 16 types of identities although identities embodied in Chinese and American real estate advertising show differences. Advertisers appeal to consumers' desire and provoke their buying motivation through these identities. For example, American real estate advertisers construct identity of dreamer by presupposing that American dream is buying house (5a).

\section{DISCUSSION}

Both American and Chinese real estate advertisers construct identities of winner and family which reflect common desire of consumers to some extent. According to Maslow's hierarchy of needs, identities of winner and family represent needs of self-actualization and love (belonging) respectively. Thus, these identities constructed are reasonable and acceptable. However, should we advocate value which equals buying house to self-actualization?

Peace seeker and individuality are frequent among identities constructed by Chinese real estate advertisers while they are rare among identities constructed by American real estate advertisers. To some extent, it reflects that Chinese are nervous in modern society due to competition and other pressure so that they desire to seek for peaceful environment to relax or a private place where they can feel free after work or study. Different from Chinese, American real estate advertisers tend to construct high-tech lover and money saver to appeal consumers' desire. Such identities in American real estate advertising show that American consumers prefer to spend low price on buying an automatic connected house. As known to us, American economy is gloomy after economic crisis and citizen are hard to buy house if they cannot get loan from bank while citizens are more difficult to receive loan from bank to buy house after economic crisis. Thus, consumers are willing to buy house when the house is on sale. In American real estate advertising, enjoyer and simple life seeker are also relatively frequent identities but they do not appear in Chinese real estate adverting. From Hofstede's six dimension [5], we know that the US is an indulgent society in which American tend to enjoy life and have fun while China is a restraint society where people are regulated by social norms. Thus, that's might be the reason why American advertisers will construct identity of enjoyer which does not appear in China real estate advertising.

Although Child education prioritized parent and time saver are not frequently constructed, they are identities embodied only in Chinese real estate advertising. China is a collective society in which 
parents shall take care of their children everything before children get married. Education as an important part of children development, is key factor influencing consumers' purchase. However, the US is an individual society in which parents ask for their children to take care of themselves in childhood so that identity of child education prioritized parent is rare in American real estate advertising. In addition, Chinese consumer prefer their house next to their workplace, shopping mall and subway station so that they can save time. To some degree, it reflects that Chinese are tired, nervous and even over-burdened.

\section{CONCLUSION}

We have confirmed that American real estate advertisers do presuppose consumers' identity in advertisements. Based on 100 electronical real estate advertisements collected from social media, 16 types of pragmatic identities are summarized from critical pragmatic analysis. They are: Winner / Champion/ Victor (pursue victory), Peace seeker, Family (love home), Individuality, Nature lover, Dreamer, Child (full of imagination), Time saver, Child education prioritized parent, Extravert, hightech lover, Sport lover, Quality prioritized realist, Money saver, Enjoyer and Simple life seeker. Both American and Chinese advertisers prefer to use implicit linguistic resources to construct consumers' identity although explicit linguistic expressions such as champion are also used to construct identity. In addition, we found that the major reasons for advertisers to construct these pragmatic identities are to appeal and provoke consumers' purchase desire according to Maslow's hierarchy of needs including belonging (love) and self-realization. Differences of identities founded in Chinese and American real estate advertising can be explained by Hofstede's cultural dimensions. For example, the US is an indulgent society while China is a restraint society so that enjoyer is only founded in American real estate advertising.

\section{References:}

1. Chen, X. R. (2009). Piping yuyongxue: Mubiao duixiang yu fangfa. Foreign Language and Their Teaching, (12). http://www.cnki.com.cn/Article/CJFDTotal-SDWY201805003.htm

2. Chen, X. R. (2018). Pragmatic Identity: How to do things with words of identity. Beijing: Beijing Normal University Publishing Group.

3. Chen, X. R. (2018). Shangye guanggao shenfen taolu de piping yuyong fenxi. Shandong Waiyu Jiaoxue (Shandong Foreign Languages Teaching Journal), (5). http://www.cnki.com.cn/Article/CJFDTotal-WYWJ200912002.htm

4. Cui, Y. \& Zhu, Y. X. (2008). Zhongxi fangdichan guanggao huhuan gongneng de shixian. Yuwen Xuekan (Journal of Language and Literature Studies), (23). http://www.cnki.com.cn/Article/CJFDTotal-YWXK200823031.htm

5. Hofstede, G., Hofstede, G. J. \& Minkov, M. (2010). Cultures and Organizations: Software of the Mind (3rd edition). New York: McGraw-Hill.

6. Li, J. (2008). Zhongwen fangdichan guanggao yanjiu de pipingxing yupian shijiao. Anhui Wenxue (Journal of Anhui Literature), (2). www.cnki.com.cn/Article/CJFDTotal-AHWA200802158.htm

7. Li, Y. (2014). Cong piping huayu fenxi shijiao kan fangdichan de wenhua suqiu. Shenyang Nongye Daxue Xuebao (Journal of Shenyang Agricultural University), 16(4). http://www.cnki.com.cn/Article/CJFDTotalSYLD201404035.htm

8. Lu, X. D. (2011). Fangdichan guanggao yupian de hudong yiyi jiedu. Hubei Caijing Gaodeng Zhuanke Xuexiao Xuebao (Journal of Hubei College of Finance and Economics), 23(1). http://www.cnki.com.cn/Article/CJFDTotalHBGZ201101023.htm

9. Mey, J. (1993). Pragmatics: An Introduction. Oxford: Blackwell. 
Yilin, X. (2020) Pragmatic Identity in China and the US Real Estate Advertising: Critical Pragmatic Analysis. Advances in Social Sciences Research Journal, 7(5) 393-404.

10. Robinson, R. L (1996). White Cultural Matrix and the Language of Nonverbal Advertising in Housing Segregation: Toward an Aggregate Theory of Liability. 25 Capital University Law Review.

11. https://heinonline.org/HOL/LandingPage?handle=hein.journals/capulr25\&div=13\&id=\&page=

12. Wang. S. Y. (2011). Lun fangdichan guanggao yingyi de shunyingguan. Hunan Gongye Daxue Xuebao (Journal of Hunan University of Technology), 16(3). http://www.cnki.com.cn/Article/CJFDTotal-ZZSF201103025.htm

13. Yang, L. (2009). Fangdichan guanggao dui xiaofeizhe fuguishenfen de yushe qingxiang. Xinwen Shijie (News World), (6). http://www.cnki.com.cn/Article/CJFDTotal-PXWS200906056.htm

14. Zhu, C. F. (2008). Fangdichan guanggao yuyan de huwenxing fenxi. Zhejiang Chuanmei Xueyuan Xuebao (Journal of Zhejiang Institute of Medial Communication), (2). http://www.cnki.com.cn/Article/CJFDTotalCMXB200802015.htm 